groups to sensible research projects.

With physical anthropology under a cloud for its habit of using measurable skeletal indices as proxies for less tangible attributes (cranial capacity as a measure of intelligence, for example), it would be better to invest what goodwill there is in some quite different field. The Human Genome Diversity Project is already battling to win the consent of distinctive racial groups to schemes for collecting and analysing DNA. The goal is a better understanding of human evolution in the past 250,000 years or so. It is an important goal, from which all races will benefit. Such a project is unlikely to answer Bannister's question directly (nor can it say anything about mean IQ), but it could provide us all with a much better appreciation than we have at present of the wealth and interest of human diversity, and of the importance of the genetic constitution we have in common.

\section{New ways with wealth}

The World Bank is devising a measure of national wealth that will be confusing if taken seriously.

NotHING if not daring, the World Bank has devised a new measure of national wealth that is certain to capture wide attention because it relegates former top dogs to more lowly status in the international pecking order. For example, Australia comes out on top, Luxembourg and Switzerland are ahead of Japan, the United States is merely twelfth on the list, France stands higher than Germany and Britain is twenty-second, below Finland, Italy and the Netherlands. It is all good knock-about fun for the newspapers, but the bank's purpose is serious: to devise a numerical measure of national well-being that will be more appropriate to the assessment of sustainable development than old-fashioned gross national product (GNP) per head of population. The goal is laudable, but the method will set economists quarrelling among themselves (and with the bank) for months to come.

Environmentalists for many years have been fond of pouring scorn on GNP as a measure of anything that matters, and nobody denies that paradoxes abound. Suppose that a country is afflicted with an environmental problem, say a bad spill of radioactivity, and has to spend $\$ 1$ billion to clean up the mess. Evidently, the critics say, the quality of people's lives will have declined, yet the GNP will increase by a total of $\$ 1$ billion over the duration of the clean-up operation. In what sense, the complaint goes, can this needless expenditure be said to increase a nation's wealth? And can it really be accepted as true that the country would be worse off if it declined to clean up the mess, robbing its GNP of the $\$ 1$ billion in the process?

The reality is not like that, of course. GNP is not a measure of wealth, but of economic activity. Technically, it is an accident, although not a surprising one, that GNP per head is closely correlated with the sense of well-being that a country's residents enjoy. After all, on one definition, GNP is the aggregate of salaries and other payments to individuals. In any case, the World Bank proposes taking a radically different line, defining the "wealth of nations" (it actually uses Adam Smith's term) in terms of asset values, tangible and otherwise. These come in four categories: natural capital (or the economic value of natural resources), "produced assets" (meaning the value of a country's built infrastructure), human resources (or the value represented by people's productive capacity) and social capital (described but not defined as the productive value of people collectively rather than individually).

At this stage, the World Bank's daring cannot be doubted. Economists will find plenty to quarrel about. Even the most tangible part of the bill of goods, called natural capital, cannot be estimated unambiguously. How, for example, is it possible to estimate the value of a buried asset except by the yardstick of a market price, no doubt abated by the estimated cost of extraction? And what happens when the prices of natural resources change relative to each other? Or when changing circumstances mean that a natural resource is no longer exploitable?

That is what has happened to Britain's coal reserves, described by W. Stanley Jevons a century ago as the foundation of Britain's then-prosperity, under the pressure of rising wages (a consequence of prosperity) and the prevailing 'not in my backyard' syndrome. By the same test, Jamaica does well in the new pecking order of wealth (at ninety-second) because its bauxite has been recognized as worthwhile within the past century (before which it had no value). Similarly, Papua New Guinea is listed above Latvia and Thailand on the strength of its recently discovered copper. The moral is that even the natural capital element in the new index of national wealth will have to be radically adjusted from time to time as the value of buried wealth changes. Will Qatar be eighth in the World Bank's list of the wealthy if thermonuclear fusion proves to be cheap?

Arguments about the valuation of human capital will be even more vigorous. Is this determined by the average cost of schooling, or by other criteria? In the estimation of the contribution to a country's wealth made by a motorway or a railway, should some account be taken of the degree to which the facility is used, or how it may be used in future? Counting the capacity of pin-heads to accommodate angels may be easier than answering these and related questions. But the valuation of social capital is an even more dangerous can of worms: who is to assess the relative value of a golf-club and parent-teacher association?

So far as can be told, the World Bank has set out to construct what businesspeople would call a balance sheet, not the single line called 'turnover' in a standard profit-and-loss account which is at present measured by GNP. (On present performance, 'social capital' is the equivalent of the intangible called 'goodwill'.) The World Bank's press release on the subject is misleading, suggesting that the new index is a better measure of wealth when it is merely a different measure. The whole question is to be discussed at length at a conference in Washington next month. The authors of this brave exercise deserve to have some well-wishers in the audience. In the interests of good sense, it is to be hoped that that there will also be some traditionalists. 